\title{
A ESCRITA NA UNIVERSIDADE: OS DESAFIOS DA AQUISIÇÃO DOS GÊNEROS ACADÊMICOS
}

\section{WRITING AT UNIVERSITY: THE CHALLENGES TO THE ACQUISITION OF GENDER ACADEMIC}

\author{
Adriana Demite Stephani ${ }^{1}$ \\ Tauana da Cunha Alves ${ }^{2}$
}

RESUMO: $O$ presente texto traz os resultados de uma pesquisa que buscou identificar as recorrentes dificuldades encontradas por estudantes universitários no processo de aquisiçâo da escrita, mais especificadamente de gêneros acadêmicos (artigos, resenhas, resumos, fichamento, dissertaçăo, tese, livros teóricos, projetos de iniciaçâo científica). Como se sabe, a graduaçăo exige dos discentes a aquisiçăo leitura e escrita científicas năo apenas de conteúdos de textos, mas de diversas linguagens ou gêneros típicos do nível acadêmico. No entanto, essa apropriaçăo é árdua e nem sempre bem sucedida entre os universitários. Para conhecer um pouco sobre essa realidade foi aplicado um questionário semiestruturado, composto de 7 (sete) questóes, aos alunos do curso de Pedagogia do $8^{\circ}$ e $9^{\circ}$ períodos da Universidade Federal do Tocantins, Campus de Arraias-TO. Os dados coletados evidenciaram que os hábitos de leitura e escrita de gêneros textuais acadêmicos săo ínfimos diante do que se espera para esse nível de ensino. Essa realidade se dá como reflexo da dificuldade de compreensăo e da pouca leitura dos gêneros textuais acadêmicos (GTAs) por parte dos universitários, da escassa explanaçăo sobre o processo de construçăo desses gêneros, bem como, pela forma de correçâo e avaliaçâo dos gêneros acadêmicos (GTAs), considerada pelos universitários como insuficiente para o real letramento acadêmico.

Palavras-chave: Letramento. Escrita. Gêneros Textuais Acadêmicos. Universidade.

ABSTRACT: This text presents the results of a study that sought to identify the recurrent difficulties encountered by university students in the writing acquisition process, more specifically of academic genres (articles, reviews, abstracts, book report, dissertation, thesis, theoretical books, initiating projects scientific). As it's known, the university course requires of the students the acquisition of the reading and writing scientific not only text content but different languages or typical level of academic genres. However, this appropriation is arduous and not always successful among university students. To know a little about this reality was applied a semi-structured questionnaire, composed of seven questions, for the 8th and 9th periods of the Pedagogia Course students (Federal University of Tocantins, Campus Arraias-TO). The data collected showed that the reading and writing academic genres habits are so few before what is expected for this level of education. This reality occurs as a result of the difficulty of understanding

Doutora em Letras/Literatura pela UnB. Professor Adjunto I da UFT. E-mail: astephani@uft.edu.br.

Licenciada em Pedagogia pela UFT. E-mail: tauana@mail.uft.edu.br. 
and little reading of academic genres (GTAs) by the university, the little explanation of the process of building these genres as well, by way of correction and evaluation of academic genres (GTAs), considered by the universities as insufficient for a real academic literacy.

Keywords: Literacy. Writing. Academic genres. University.

\section{INTRODUÇÃO}

Num mundo grafocêntrico como o nosso, possuir o bom domínio da leitura e escrita possibilita ao indivíduo compreender melhor tal mundo e desfrutar de oportunidades que quem năo possui tal domínio lograria. Todavia, isso năo é acessível a um grande número de pessoas, mesmo com o constante avanço nos números e índices sobre a alfabetizaçăo da populaçâo brasileira.

Em tese, no meio acadêmico essa realidade seria distinta, pois se acredita que aqueles que adentram o espaço universitário já adquiriram a habilidade de ler e escrever em um nível mais avançado. Todavia, pesquisas apontam que esse espaço é apenas uma sequência das mazelas e lacunas nessas áreas e tal problemática tem gerado inúmeras discussóes e debates: o que fazer diante dessa realidade? Ela é comum a todos que adentram os cursos e universidades? Tal realidade impacta na aquisiçăo do letramento acadêmico?

Segundo Marinho (2010, p. 364), as “constantes queixas de professores universitários (e dos próprios alunos) de que os alunos têm dificuldade na leitura e na produçâo de textos acadêmicos nos alertam para a necessidade de transformar essas queixas em propostas de ensino e de pesquisa".

Diante disso, faz-se oportuno que pesquisas sejam realizadas constantemente para cartografar essa realidade e propor alternativas na tentativa de mudar esse atual e preocupante contexto. Isso é o que muitas universidades já estăo realizando e entre elas está Universidade Federal do Tocantins, Campus de Arraias, que desenvolve desde 2010 um projeto de pesquisa de caráter contínuo intitulado "A Leitura e a produçâo textual na graduaçăo: o real e o ideal" e que abarca diversos subprojetos com etapas anuais. Os resultados que aqui săo apresentados săo de uma dessas fases de investigaçâo (feita com alunos do $8^{\circ}$ e $9^{\circ}$ período do curso de Pedagogia) que objetivou, especificamente, investigar a produçâo da escrita no meio acadêmico, junto com as práticas de letramento e sua importância para o processo de formaçăo do futuro professor.

Ademais, como nesse novo espaço educacional que é o ensino superior onde os alunos devem ampliar seu letramento se apropriando também dos gêneros acadêmicos, é salutar observar como acontece essa nova apropriaçăo, uma vez que, como pontua Fiad (2011, p. 362), "nâo há uma correspondência entre o letramento do estudante e o letramento que lhe é exigido na universidade". Isso porque, o trabalho de ensino e aprendizagem da escrita acadêmica náo é uma "estratégia compensatória, interessada em oferecer aos alunos, que têm dificuldades de leitura e de escrita, a oportunidade de recompor lacunas de um processo de escolarizaçăo supostamente deficitário, de aprender aquilo que deveriam ter aprendido antes de entrar na universidade" (MARINHO, 2010, p. 371), mas sim, um novo processo de letramento e este deve se constituir no âmbito universitário, onde certos gêneros circulam. 


\title{
LETRAMENTO: DA VIDA À ACADEMIA
}

Na sociedade atual em que vivemos, saber ler e escrever năo é suficiente para preencher os requisitos exigidos no mercado, pois é necessário năo apenas decodificar códigos, mas sim entender os significados do uso da leitura e da escrita na prática e vida social. É o que diz Fiad (2011, p. 360): “antes, era possível ver o desempenho na escrita como habilidades individuais de ler e escrever, adquiridas principalmente na escola, hoje é necessário situar qualquer prática envolvendo a leitura e a escrita em um contexto sócio-histórico-cultural específico".

Ao mostrar essa exigência cada vez maior de ampliaçâo do nível de letramento também no ensino superior, a autora ainda complementa: "contrariamente ao que dizem muitos professores universitários em relaçâo à escrita de seus alunos, entendo que esses estudantes săo letrados, só năo se engajaram ainda nas práticas letradas esperadas no contexto acadêmico" (FIAD, 2011, p. 360, grifos nossos).

O termo surgiu e estava atrelado, a priori, a princípios aos anos iniciais de escolarizaçăo, ampliando a ideia de ensinar a ler e escrever para ensinar a fazer uso da leitura e da escrita de forma efetiva. Segundo Almeida e Farago (2014, p. 211):

\begin{abstract}
Através do Letramento, passou-se a entender que, nas sociedades contemporâneas, era insuficiente o mero aprendizado das "primeiras letras", e que integrar-se socialmente, envolve também saber utilizar a língua escrita nas situaçóes em que esta é necessária, lendo e produzindo textos.
\end{abstract}

Porém, ao contrário do que muitos pensam, o meio escolar năo é único lugar onde ocorre o letramento. $O$ indivíduo pode letrar-se em diferentes áreas do conhecimento e situaçóes humanas. No que tange ao letramento linguístico, este pode ocorrer em vivência em contextos onde haja situaçôes que estimulem a leitura e a escrita e que façam uso dela, como também estimulem o desenvolvimento da expressáo oral e comunicativa dos seres. Nesse sentido, como apontam Almeida e Farago,

\begin{abstract}
[...] pode ser considerado letrado mesmo quem năo seja alfabetizado, na medida em que ao participar de contextos de letramento utiliza estratégias orais dos conhecimentos construídos sobre a língua que se escreve, mesmo sem saber ler e escrever conhece a estrutura da língua escrita. (2014, p. 213)
\end{abstract}

A cultura e a sociedade também săo fatores que influenciam nesse processo, como bem pontua Fiad (2011): "as práticas de uso da escrita săo diferentes, é possível assumir que existem múltiplos letramentos, a depender das esferas e grupos sociais: escolar, religioso, familiar".

Compreende-se que cada pessoa ou grupo social possui algum tipo de conhecimento sobre a escrita, bem como, de seu uso em práticas em sua vida. E, a história de cada estudante e o conhecimento construído ao longo de sua trajetória, náo podem ser desconsiderados. Desta forma, entende-se que há práticas de letramento comuns a todos os contextos da vida, da educaçâo básica até a academia.

Sendo assim, para falarmos sobre letramento é importante que saibamos a diferença de um sujeito letrado para o alfabetizado e compreender que sáo termos diferentes, entretanto, podem ser interdependentes. Tentando elucidar melhor a questăo, Almeida e Farago (2014, p. 205) exemplificam a diferença entre alfabetizaçăo e letramento: 
[...] alfabetizado é aquele aluno que conhece o código escrito, sabe ler e escrever. Desse modo, letramento, designa a açáo educativa de desenvolver o uso de práticas sociais de leitura e escrita em contextos reais de uso, inicia-se um processo amplo que torna o indivíduo capaz de utilizar a escrita de forma deliberada em diversas situaçōes sociais. (ALMEIDA; FARAGO, 2014, p. 205)

Vivemos em uma sociedade que está em constantes mudanças, desta forma quando novos fenômenos surgem é necessário dar um nome a este fato, neste caso aos novos comportamentos de práticas sociais de leitura e escrita. Cunha (2012, p. 136) explica que,

[...] o surgimento do vocábulo pode ser entendido como configuraçăo necessária para nomear comportamentos sociais no ato de aprendizagem e da prática da leitura e da escrita, que extrapolam os procedimentos de decodificaçăo do sistema alfabético e ortográfico, em outras palavras, os procedimentos habituais do processo de alfabetizaçăo. (CUNHA, 2012, p. 136)

Nas palavras de Soares (2009, p. 39), "[...] letramento é o resultado da açăo de ensinar e aprender as práticas sociais de leitura e de escrita, estado ou condiçăo que adquire um grupo social ou um indivíduo como consequência de ter-se apropriado da escrita e de suas práticas sociais".

Ainda segundo a autora, um indivíduo pode năo saber ler e escrever, isto é, ser analfabeto, mas ser de certa forma, letrado. Um adulto que náo sabe ler e escrever, mas que tem o costume de ouvir a leitura de livros, jornais, dita cartas para que outros redijam é um ser letrado, se envolve em práticas sociais de leitura e escrita (SOARES, 2009, p. 24). Desta forma, entender letramento é reconhecer que cada indivíduo possui algum tipo de conhecimento sobre a escrita e seu uso em práticas sociais, sendo assim é um ser letrado. Seguindo essa linha de raciocínio,

[...] um indivíduo alfabetizado náo énecessariamente um indivíduo letrado. Alfabetizado é aquele indivíduo que sabe ler e escrever. Já o indivíduo letrado, o indivíduo que vive em estado de letramento, é năo só aquele que sabe ler e escrever, mas aquele que usa socialmente a leitura e a escrita, pratica a leitura e a escrita responde adequadamente às demandas sociais de leitura e de escrita. (SOARES, 2002, p. 40)

Além do mais, é possível letrar-se em diversos gêneros sendo que cada um

[...] tem as suas normas: a estrutura e a organizaçăo do texto. Os recursos de coesăo textual, os níveis de informatividade, a própria disposiçăo do texto na página năo săo os mesmos, se trata de uma narrativa, de uma dissertaçăo, de uma argumentaçáo, de um editorial, de uma notícia de jornal, de uma receita culinária. (SOARES, 2001, p. 64)

Nesse sentido, o letramento que aqui abordamos está diretamente ${ }^{3}$ ligado ao uso prático da leitura e escrita. De forma direta, pode-se dizer que é um conjunto de práticas sociais, onde o indivíduo é capaz de associar escrita ao seu contexto social. Nấo basta apenas a aquisiçâo desta, mas é necessário utilizá-la interpretando e posicionando de forma crítica.

3 Aqui nâo desconsideramos os diversos adjetivos que săo agregados ao termo letramento; apenas nesse item é feita relaçăo direta com o processo de aquisiçăo/apropriaçăo/aperfeiçoamento e uso da leitura e escrita no processo de alfabetizaçâo. Hoje há diversas áreas de estudos que fazem uso da terminologia: letramento linguístico, matemático, digital, acadêmico etc. 
Para Soares (2009, p. 18), "letramento é o "estado" ou a "condiçăo" que o indivíduo ou o grupo social passam a ter, sob o impacto dessas mudanças". Impacto este que muitos alunos vêm sofrendo ao iniciar a vida acadêmica, pois se deparam com informaçóes que, até entâo, eram desconhecidas em fase escolar anterior, no Ensino Médio. Ainda, para a autora, "letramento náo é pura e simplesmente um conjunto de habilidades individuais; é o conjunto de práticas sociais ligadas à leitura e a escrita em que os indivíduos se envolvem em seu contexto social" (SOARES, 2009, p. 72).

Vivendo numa sociedade em que cada vez mais se exige do profissional o aperfeiçoamento de outras habilidades. O uso efetivo da leitura e escrita deixou de ser apenas necessidade intelectual ou de alfabetizaçấo do indivíduo para transformar-se em condiçăo de sobrevivência no meio social, pois, no momento em que o indivíduo passa a ter prática e domínio das ferramentas de leitura e escrita, ele consegue enxergar seu modo de viver na sociedade e sua realidade com outro olhar. Essa exigência leva muitas vezes a uma mecanizaçâo do conhecimento, levando ao chamado letramento autônomo apontado por Lea e Street (1998; 2006).

Neste sentido, é esperado de um estudante - e muito mais de um do Ensino Superior que possua capacidade de analisar, interpretar e avaliar o conhecimento através da sua escrita, ligar a teoria e a prática, analisar, ser crítico, utilizar uma linguagem adequada as suas intençóes, expressar sua opiniăo e fazer interpretaçōes pessoais dos fatos, de acordo com os objetivos, gêneros textuais e abordagens de escrita exigidas no ensino superior. Ou seja, adquira e desenvolva um letramento acadêmico.

E o que seria esse letramento?

O letramento acadêmico parte do princípio de que é necessário ter o domínio em formas de produçấo, leitura e escrita dos determinados Gêneros Textuais Acadêmicos (doravante GTAs), sendo estas características primordiais para a formaçâo do estudante, pois é o resultado de um processo de desenvolvimento de habilidades e percepçóes referentes às formas de interagir com a escrita nesse domínio social. Como afirma Fischer (2008, p. 180), “o letramento característico do meio acadêmico refere-se, nessa direçăo, à fluência em formas particulares de pensar, ser, fazer, ler e escrever, muitas das quais sáo peculiares a esse contexto social".

Sobre letramento acadêmico Souza e Basseto dizem que:

entendemos comunidade acadêmica como uma comunidade discursiva própria, cujos membros compartilham determinado discurso acadêmico (por exemplo, o científico, administrativo etc.) como forma de sustentar os sistemas de crenças da comunidade e que, com base nos gêneros textuais próprios dessa comunidade - que chamamos aqui de gêneros acadêmicos -, materializam seus discursos com propósitos comunicativos variados, como conseguir financiamentos para pesquisas, divulgar pesquisas em eventos acadêmicos, relatar experiências etc. (SOUZA; BASSETO, 2014, p. 87).

Conforme Cunha (2012, p.139), "o letramento acadêmico é como o letramento nos níveis escolares de base, um processo de desenvolvimento de práticas e comportamentos sociais que interagem continuamente com a escrita".

Lea e Street vấo além dessa definiçăo e mencionam que "a aprendizagem no ensino superior implica a adaptaçăo a novas formas de saber: novas maneiras de compreender, interpretar e organizar o conhecimento" (1998, p. 157). 
As autoras apontam três abordagens referentes à escrita do estudante universitário identificadas como: o modelo das habilidades de estudo, da socializaçăo acadêmica e dos letramentos acadêmicos. (LEA; STREET, 1998)

De acordo com a primeira abordagem, o letramento é entendido como um conjunto de habilidades individuais e cognitivas que os estudantes precisam adquirir e desenvolver. Adquiridas, essas habilidades seriam transferidas a outros contextos de escrita da universidade. No modelo da socializaçáo acadêmica, o professor é quem vai introduzir os alunos na cultura universitária, de forma que se apropriem dos modos de falar, raciocinar, interpretar e escrever nas disciplinas e temas próprios dessa instituiçăo. Dentro desse modelo, gêneros discursivos acadêmicos sáo relativamente homogêneos e, aprendendo convençôes que regulam esses gêneros, conseguirăo participar das práticas letradas próprias dessa esfera. Já a última abordagem entende os letramentos como múltiplos, como práticas sociais e, nesse sentido, constituem o fazer da esfera acadêmica, e constituem uma outra forma de compreender, interpretar e organizar o conhecimento. (KERSCH, 2014, p. 56)

Sobre ser academicamente letrado, Fischer (2008, p. 181) destaca que

um aprendiz tem um repertório de estratégias efetivas para compreender e usar as diferentes linguagens, especializadas e contextualizadas, no domínio acadêmico. Ainda, indica os papéis sociais (pelo menos desejáveis) de alunos e professores, as finalidades de os alunos estarem neste domínio e as relaçóes estabelecidas com o conhecimento e com o saber.

Sendo assim, falar de letramento acadêmico é, pois, falar de agir no mundo e năo de uma técnica aprendida pela repetiçăo, totalmente desassociada da realidade. A universidade é um espaço organizado por diversas práticas sociais, em que săo necessários que os alunos, sujeitos letrados, mostrem suas habilidades com a escrita.

Já mencionamos que o letramento acadêmico se configura como as práticas sociais (ou acadêmicas) de uso da língua oral e/ou escrita, ou seja, o domínio dos Gêneros Textuais Acadêmicos (GTAs). No entanto, para melhor compreender esses gêneros específicos primeiramente faz-se pertinente entender o conceito de gênero textual. Para Aranha (2004, p. 29),

[...] o gênero se estabelece dentro de uma comunidade discursiva e ela tornase responsável por ele. Poderíamos sugerir que existe um processo de autoalimentaçấo: a comunidade discursiva desenvolve determinados gêneros e a existência de gêneros específicos configura grupos sociais como comunidades discursivas por compartilharem propósitos comunicativos efetivados através dos gêneros pertinentes a ela.

Assim, a gênese e o estabelecimento de um gênero ocorrem dentro de uma comunidade linguística. Para expandir nossa discussăo, fazemos uso nessa pesquisa dos princípios e conceitos apontados por Marcuschi (2003, p. 19) que propóe uma noçáo de gênero visto,

[...] náo como instrumentos estanques e enrijecedores da açăo criativa, mas sim, como eventos textuais altamente maleáveis, dinâmicos e plásticos. Surgem emparelhados a necessidades e atividades socioculturais, bem como, na relaçăo com inovaçōes tecnológicas, o que é facilmente perceptível ao se considerar a quantidade de gêneros textuais hoje existentes em relaçấo a sociedades anteriores à comunicaçấo escrita. 
Ou seja, para o autor, os gêneros sâo manifestaçóes linguísticas em nossa sociedade que surgem a partir das necessidades de comunicaçáo. E possível encontrar em sua obra, por exemplo, que:

Após a invençăo da escrita alfabética por volta do século VII A.C., multiplicam-se os gêneros, surgindo os típicos da escrita. Numa terceira fase, a partir do século $X V$, os gêneros expandem-se como flores cimento da cultura impressa para, na fase intermediária de industrializaçăo iniciada no século XVIII, dar início a uma grande ampliaçáo. Hoje, em plena fase da denominada cultura eletrônica, com o telefone, o gravador, o rádio, a TV e, particularmente o computador pessoal e sua aplicaçăo mais notável, a internet, presenciamos uma explosăo de novos gêneros e novas formas de comunicaçăo, tanto na oralidade como na escrita. (MARCUSCHI, 2003, p. 20)

Isto mostra de fato que os gêneros textuais surgem, a partir das culturas em que se desenvolvem de acordo com cada contexto social. A noçấo de gêneros proposta por Marcuschi (2003, p. 23) é a de que "toda a postura teórica desenvolvida se insere nos quadros da hipótese sócio-interativa da língua. É neste contexto que os gêneros textuais se constituem como açóes sócio-discursivas para agir sobre o mundo e dizer o mundo, de algum modo". O autor destaca que é importante fazer a distinçáo entre "tipo textual" e "gênero textual" e defende que "é impossível se comunicar verbalmente a nâo ser por algum gênero, assim como é impossível se comunicar verbalmente a nâo ser por algum texto. Em outros termos, partimos da ideia de que a comunicaçăo verbal só é possível por algum gênero textual" (MARCUSCHI, 2003, p. 22 grifos do autor). Ainda, afirma que:

Em geral, a expressăo "tipo de texto", muito usada nos livros didáticos e no nosso diadia, é equivocadamente empregada e năo designa um tipo, mas sim um gênero de texto. Quando alguém diz, por exemplo, "a carta pessoal é um tipo de texto informa!", ele náo está empregando o termo "tipo de texto" de maneira correta e deveria evitar essa forma de falar. Uma carta pessoal que você escreve para sua máe é um gênero textual, assim como um editorial, horóscopo/ receita médica, bula de remédio, poema, piada, conversaçáo casual, entrevista jornalística, artigo científico, resumo de um artigo, prefácio de um livro. É evidente que em todos estes gêneros também se está realizando tipos textuais, podendo ocorrer que o mesmo gênero realize dois ou mais tipos. (MARCUSCHI, 2003, p. 26)

Assim percebemos que entre as características básicas dos tipos textuais está o fato de eles:

[...] serem definidos por seus traços linguísticos predominantes. Por isso, um tipo textual é dado por um conjunto de traços que formam uma sequência e năo um texto. A rigor, pode-se dizer que o segredo da coesáo textual está precisamente na habilidade demonstrada em fazer essa "costura" ou tessitura das sequências tipológicas como uma armaçăo de base, ou seja, uma malha infraestrutura do texto. Como tais, os gêneros săo uma espécie de armadura comunicativa geral preenchida por sequências tipológicas de base que podem ser bastante heterogêneas, mas relacionadas entre si. Quando se nomeia um certo texto como "narrativo","descritivo" ou "argumentativo", năo se está nomeando o gênero e sim o predomínio de um tipo de sequência de base. (MARCUSCHI, 2003, p. 28)

Marcuschi (2003, p. 31) assevera que "quando dominamos um gênero textual, nâo dominamos uma forma linguística e sim uma forma de realizar linguisticamente 
objetivos específicos em situaçóes sociais particulares". Desta forma, considera-se que o contato com os gêneros textuais é uma grande oportunidade de ter contato com a língua em seus mais diversos usos, pois nada do que fizermos linguisticamente estará fora de ser feito em algum gênero. É importante salientar também que, ao produzir qualquer gênero textual a impessoalidade, a objetividade, a clareza e a coerência sáo fundamentais para sua construçáo.

Ainda trazendo definiçōes e discutindo a importância dos gêneros textuais, recorremos ao que pontuam os Parâmetros Curriculares Nacionais (PCN) que propóem e justificam a inclusăo destes no ensino da Língua Portuguesa, mencionando que é

[...] necessário contemplar, nas atividades de ensino, a diversidade de textos e gêneros, e năo apenas em funçăo de sua relevância social, mas também pelo fato de que textos pertencentes a diferentes gêneros săo organizados de diferentes formas. A compreensáo oral e escrita, bem como a produçâo oral e escrita de textos pertencentes a diversos gêneros, supóem o desenvolvimento de diversas capacidades que devem ser enfocadas nas situaçôes de ensino. É preciso abandonar a crença na existência de um gênero prototípico que permitiria ensinar todos os gêneros em circulaçấo social. (BRASIL, 1998, p. 23-4)

Sobre a importância do trabalho com os gêneros textuais, Gonçalves também se posiciona:

Sem dúvida, é o trabalho com os gêneros textuais que permite diversas formas de interaçăo no processo de ensino e aprendizagem, entre elas, o contato direto com a língua, a compreensáo do sistema linguístico e suas variaçóes, a capacidade de análise, entre outras. Dessa forma, a nosso ver, a análise de gêneros é tema importante e essencial na formaçăo e capacitaçáo de docentes, independentemente do nível em que ele atua. (GONÇALVES, 2012, p. 130)

A utilizaçăo de textos de diferentes gêneros no processo de ensino e aprendizagem é essencial para a vida do estudante, inclusive a do universitário, pois, é a partir destes que se aprende a aperfeiçoar a expressâo e a melhor compreender a linguagem oral e escrita. Desse modo, percebe-se o quáo importante os gêneros textuais acadêmicos (GTAs) sâo para formaçâo profissional e acadêmica dos universitários. E o que seriam os GTAs?

Segundo Souza e Basseto (2014, p. 86), os gêneros acadêmicos săo entendidos, como os textos escritos que sâo produzidos e que circulam no âmbito universitário como meio de comunicaçâo entre professores, pesquisadores e alunos, com diferentes propósitos comunicativos como, por exemplo, divulgaçăo de pesquisa, resumo de ideias, relatórios de atividades. Os textos mais solicitados para leitura e produçấo no meio acadêmico săo: fichamento, resumo, resenha, artigo, projeto, memorial, relatório (de estágio e de pesquisa), monografia, dissertaçăo e tese.

De acordo com Dorsa (2013), os gêneros resumo, resenha, relatórios, projetos e Apresentaçâo de trabalhos orais e escritos săo os mais solicitados para a produçâo na universidade. A autora também menciona que quanto "ao gênero de divulgaçăo, o artigo é o gênero textual mais utilizado por pesquisadores, docentes e discentes visando à divulgaçăo científica do trabalho produzido" (DORSA, 2013, p. 106). E, cabe ressaltar que os demais GTAs sâo solicitados quanto à leitura e raramente solicitam-se suas produçōes. 


\section{A ESCRITA ACADÊMICA NA PRÁTICA: ESTUDO DE CASO}

Após realizar um levantamento teórico sobre o letramento acadêmico, optamos - para ilustrar esse processo - por realizar uma pesquisa com alunos do curso de Pedagogia da Universidade Federal do Tocantins, Campus Universitário de Arraias. Nosso intento foi de investigar qual era a relaçăo desses universitários com os gêneros textuais acadêmicos, tanto na leitura quanto na escrita, para verificar se o letramento acadêmico ocorre de fato no lócus pesquisado.

Como outrora já mencionado, a escolha do determinado tema para investigaçăo se deu pelo interesse em averiguar os efeitos e lacunas do curso quando nos referimos à formaçăo dos estudantes, com relaçăo à aquisiçăo e utilizaçăo de gêneros textuais que sâo exclusivamente conhecidos no meio acadêmico, ou seja, leitura e produçâo desses gêneros.

Para atingir tal objetivo, fez-se necessário a escolha de instrumento e lócus de pesquisa que melhor expressassem a relaçăo de alunos com os gêneros textuais acadêmicos. Assim, optamos por realizar uma pesquisa com elaboraçăo de um questionário semiestruturado para ser aplicado a alunos concluintes do curso de Pedagogia da UFT/ Arraias. Além de estarem na fase final do curso (último ano, $8^{\circ}$ e $9^{\circ}$. períodos), como já cumpriram mais metade da carga horária exigida pela universidade, tiveram a oportunidade de, nas diferentes disciplinas cursadas, ter contato com diferentes gêneros textuais acadêmicos, tanto para leitura quanto escrita. Ainda, ao investigar os dois períodos, oportunizamos dar voz a alunos dos turnos matutino e noturno, que possuem perfis diferentes no que se refere à idade, disponibilidade para estudos e espaço entre o término do EM e a entrada na Universidade.

Para a realizaçâo dessa pesquisa e com intento de atingir os objetivos propostos, foi necessária a definiçăo de um método de investigaçăo para melhor orientar nossos passos. A linha de pesquisa escolhida para realizaçăo desse trabalho foi o método qualitativo. De acordo com Minayo (2012), o verbo principal da análise qualitativa é compreender. Compreender, segundo ele, é exercer a capacidade de colocar-se no lugar do outro, tendo em vista que como seres humanos, temos condiçôes de exercitar esse entendimento (MINAYO, 2012).

A pesquisa realizada parte do princípio da catalogaçăo, descriçâo e análise dos dados coletados. $O$ trabalho de descriçăo tem caráter fundamental em um estudo qualitativo, pois é por meio dele que os dados săo coletados (MANNING, 1979, p. 668 apud NEVES, 1996, p. 1).

O estudo foi realizado na universidade sem a interferência na realidade dos sujeitos envolvidos com a finalidade de analisar os fenômenos através de questionário. Segundo Gil (2006, p. 128), o questionário pode ser definido "como a técnica de investigaçâo composta por um número mais ou menos elevado de questōes apresentadas por escrito às pessoas, tendo por objetivo o conhecimento de opiniōes, crenças, sentimentos, interesses, expectativas, situaçōes vivenciadas etc.".

O questionário aplicado possui perguntas abertas e fechadas. Com as abertas - que segundo Chaer, Diniz, Ribeiro (2011, p. 262) sâo aquelas que permitem liberdade ilimitada de respostas ao informante - objetivou-se captar a linguagem própria do respondente, como também, propiciar a vantagem de năo haver influência das respostas 
pré-estabelecidas pelo pesquisador, pois o informante escreverá aquilo que lhe vier à mente. Já as perguntas fechadas trazem alternativas específicas para que o informante possa escolher uma delas (ou mais de uma, dependendo das alternativas e questôes) e têm como aspecto negativo a limitaçăo das possibilidades de respostas, restringindo, pois, as possibilidades de manifestaçăo do interrogado. O questionário foi aplicado a 28 alunos de duas turmas do último ano do curso de Pedagogia, a UFT Campus de Arraias (17 alunos do $8^{\circ}$. e 11 alunos do $9^{\circ}$. período).

Os dados coletados foram tabulados para que, em seguida, fossem analisados de acordo com algumas categorias estabelecidas. O questionário era composto de perguntas que visaram levantar dados sobre diferentes aspectos da produçâo de gêneros textuais acadêmicos dos alunos. Os números e informaçôes que apresentamos demonstram e buscam entender como anda o nível de letramento dos alunos quando o assunto é leitura e escrita de GTAs, e quais lacunas precisam ser preenchidas.

As questôes que foram investigadas a partir do instrumento de pesquisa podem ser organizadas em algumas categorias: Uso e conhecimento da terminologia (termos "letramento acadêmico" e "gênero acadêmico"); Incidência na produçâo e leitura dos GTAs; Quantificaçâo dos GTAs produzidos; Planejamento e organizaçâo da produçâo dos GTAs pelos professores; Açôes pós a produçâo dos GTAs; Relaçâo entre a quantidade pedida de produçâo dos GTAs e a necessária; Situaçôes marcantes sobre o processo de produçâo dos GTAs.

No intento de uma melhor associaçăo das respostas às referidas turmas pesquisadas, estas foram identificadas pelas letras A (Turma A) e B (Turma B); e, quando nos referirmos aos alunos - e para que suas identidades sejam preservadas - estes seráo identificados pela letra de sua turma (A ou B), seguidos de um número específico $(1,2,3 \ldots)$.

\section{- Uso e conhecimento da terminologia (termos "letramento acadêmico" e "gênero acadêmico")}

Com intuito de investigar e discutir as relaçōes dos alunos com a escrita na graduaçăo e com as práticas acadêmicas de letramento, questionamos aos alunos: "Quando você ouve os termos "letramento acadêmico" e "gênero acadêmico", tem clareza do que se trata?" e os números revelam um quadro preocupante: do total de entrevistados do $8^{\circ}$ período (Turma $A$ ), 59\% pouco conhecem os termos "letramento acadêmico" e/ou "gênero acadêmico", 17 \% desconhecem, e somente 12\% afirmam saber do que se trata o assunto. A turma B apresenta dados semelhantes com relaçáo ao pouco conhecimento sobre letramento sendo que $68,75 \%$ dos entrevistados pouco conhecem a terminologia. Nessa turma, observa-se que nenhum aluno desconhece totalmente sobre o assunto, pois $25 \%$ afirmam saber do que se trata.

\section{- Incidência na produçăo e leitura dos GTAs}

Na pesquisa também buscamos saber quais GTAs faziam parte da leitura desses universitários e para isso perguntamos: "Quais dos Gêneros Textuais Acadêmicos a seguir foram lidos e produzidos por você durante o curso de graduaçăo em Pedagogia [...]?" e listamos alguns para que os alunos marcassem. 
Nas respostas coletadas nesta pesquisa, observou-se que a maioria dos alunos que respondeu ao questionário realiza a leitura de vários gêneros, sendo em quantidade menor apenas dissertaçăo, tese e projeto de iniciaçăo científica (IC). Um dado interessante apresentado na pesquisa é que, no $8^{\circ}$ período, o número de alunos que afirmam já ter realizado a leitura de projetos de iniciaçăo cientifica foi de $6 \%$ e no $9^{\circ}$ período apenas $4 \%$ afirmam ter lido projetos de IC. Já no que se refere à leitura de resenhas, livros teóricos, artigos científicos, resumos, fichamentos e monografias, ambas as turmas possuem o mesmo número sendo uma quantidade mediana, já que estamos nos referindo a estudantes universitários.

O que é oportuno questionar é se as leituras realizadas foram feitas de uma forma que esses alunos conseguiram desenvolver a capacidade e as habilidades de compreensăo, reflexăo, interpretaçăo, e se contribuiu para a sua formaçăo e para o entendimento no sentido de ser usado para sua vida profissional e social.

Em seguida, foi feita a análise referente à produçâo desses alunos na universidade. Os dados a seguir mostram a quantidade de gêneros textuais produzidos por esses estudantes durante sua vida universitária, visto que este é fator importante para sua formaçấo e, a partir desses dados, podemos definir o perfil de universitários que se encontram no curso de Pedagogia, Campus de Arraias.

Ao se fazer a análise comparativa entre as turmas pesquisadas observa-se que $8 \%$ dos alunos da turma A produziram artigos científicos e somente $21 \%$ dos entrevistados da turma B afirmam ter produzido artigo científico. No que se refere a projetos de Iniciaçáo Cientifica, na turma A 8\% afirmam ter feito enquanto na turma B os números ainda sáo menores, somente $4 \%$. Em ambas as turmas as respostas ilustram que a quantidade de gêneros produzidos é baixa, e fica evidente que a situaçăo é preocupante visto que na vida de um estudante universitário é essencial a produçâo e leitura de determinados gêneros.

Dando sequência à geraçấo de dados, com objetivo de analisar o que a experiência dos alunos com a produçáo de texto, foi questionado aos alunos quais habilidades ou conhecimentos eles julgavam necessários para a produçâo dos GTAs. Destacamos a seguir as respostas de alguns alunos:

\section{$8^{\circ}$ período - Habilidades ou conhecimentos necessários para a produção dos GTAs}

\begin{tabular}{|c|c|}
\hline A5 & $\begin{array}{l}\text { Habilidade de leitura, domínio da língua portuguesa, conhecer as regras da ABNT, ortografia adequada, } \\
\text { coerência e coesão. }\end{array}$ \\
\hline A6 & $\begin{array}{l}\text { Para elaboração de um bom texto é necessário um extenso repertório de leitura, conhecimento do tema, } \\
\text { domínio do tema, buscar referencias de autores que discutem o tema. }\end{array}$ \\
\hline $\mathrm{A} 12$ & $\begin{array}{l}\text { É preciso ter um domínio da língua portuguesa, ter conhecimento preciso dos assuntos que serão } \\
\text { trabalhados e conhecer as regras para elaborar cada tipo de gênero textual. }\end{array}$ \\
\hline A14 & $\begin{array}{c}\text { Para produzi-los foi necessário a explicação do professor sobre o tipo de texto e indicação de outros } \\
\text { livros ou textos que deram embasamento teórico. Habilidades de leitura e interpretação de textos, } \\
\text { conhecimento e bom conhecedor de palavras (sentido) elementos de coesão, conhecimento mínimo } \\
\text { das normas da ABNT. }\end{array}$ \\
\hline
\end{tabular}

Fonte: Quadro elaborado a partir dos dados coletados pela pesquisadora (Maio/2016). 


\section{$9^{\circ}$ período - Habilidades ou conhecimentos necessários para a produção dos GTAs}

\begin{tabular}{c|c}
\hline B2 & $\begin{array}{c}\text { Domínio da língua portuguesa, conhecimento das normas da ABNT, estas sempre está nas leituras } \\
\text { feitas durante o curso. }\end{array}$ \\
\hline B3 & $\begin{array}{r}\text { É preciso ter para produção de gênero textuais acadêmicos, conhecimentos da ABNT, costume e gosto } \\
\text { pela leitura. }\end{array}$ \\
\hline B8 & $\begin{array}{r}\text { Considero que para produzir esses textos, o acadêmico tem que ter um certo domínio de regras } \\
\text { básicas da ABNT, ter conhecimento. }\end{array}$ \\
\hline B9 & $\begin{array}{r}\text { Creio que seja necessário ter ao menos um conhecimento mesmo que breve da ABNT e normas } \\
\text { acadêmicas enquanto significados dos termos utilizados na academia e normas gramaticais. }\end{array}$ \\
\hline B14 & $\begin{array}{r}\text { Boa habilidade de leitura interpretação e assimilação dentro e fora do livro ou texto lido. E preciso } \\
\text { que se consiga elencar com o novo conhecimento os anteriores. E um domínio da escrita e língua } \\
\text { portuguesa, não que eu possua todos os quesitos, longe disso. }\end{array}$ \\
\hline
\end{tabular}

Fonte: Quadro elaborado a partir dos dados coletados pela pesquisadora (Maio/2016).

De acordo com as respostas obtidas, percebe-se a ciência por parte dos alunos da importância do bom desenvolvimento da leitura e escrita, bem como, de se possuir um bom repertório de leitura. Observa-se que, ao relatarem sobre as habilidades que acreditam ser necessárias para produzir uma boa escrita, a maioria os acadêmicos (de ambas as turmas) enfatizam em suas falas os requisitos como leitura e conhecimento das normas da ABNT como fator principal, mas náo excluem a necessidade de possuir outras habilidades.

Sobre essas habilidades, Kersch (2014, p. 56) afirma que "para conseguir produzir gêneros da esfera acadêmica, é necessário dominar as convençôes da língua, apropriar-se dos discursos valorizados pela universidade, mas, acima de tudo, năo se pode ignorar as trajetórias individuais de letramento".

O autor complementa que a história do letramento de cada indivíduo e as representaçōes construídas ao longo dessa trajetória, entretanto, năo podem ser desconsideradas, uma vez que, todo esse conjunto de influências levará o indivíduo a se apropriar do discurso acadêmico (KERSCH, 2014)

\section{- Planejamento e organizaçăo da produçáo dos GTAs pelos professores}

Ao perguntar aos alunos se os professores solicitantes das atividades realizaram explanaçăo sobre o assunto e se exemplificaram os elementos que o constituem, as respostas obtidas nos trazem dados preocupantes:

\section{Os professores solicitantes realizarem explanação sobre esse gênero, os elementos que os constituem e a estrutura que queriam que fosse entregue?}

\begin{tabular}{c|c|c|c|c|c}
\hline $8^{\circ}$ PERÍODO & Sempre & Muitas vezes & Poucas vezes & Nenhuma vez & Não me lembro \\
\hline FICHAMENTOS & $0 \%$ & $12 \%$ & $69 \%$ & $6 \%$ & $13 \%$ \\
\hline RESUMO & $6 \%$ & $23 \%$ & $53 \%$ & $18 \%$ & $0 \%$ \\
\hline RESENHA & $6 \%$ & $18 \%$ & $53 \%$ & $23 \%$ & $0 \%$ \\
\hline ARTIGO & $6 \%$ & $6 \%$ & $35 \%$ & $24 \%$ & $29 \%$ \\
\hline
\end{tabular}

Fonte: Quadro elaborado a partir dos dados coletados pela pesquisadora (Maio/2016). 
Os professores solicitantes realizarem explanação sobre esse gênero, os elementos que os constituem e a estrutura que queriam que fosse entregue?

\begin{tabular}{c|c|c|c|c|c}
\hline 9o PERÍODO & Sempre & Muitas vezes & Poucas vezes & Nenhuma vez & Não me lembro \\
\hline FICHAMENTOS & $12 \%$ & $31 \%$ & $44 \%$ & $0 \%$ & $13 \%$ \\
\hline RESUMO & $19 \%$ & $19 \%$ & $56 \%$ & $6 \%$ & $0 \%$ \\
\hline RESENHA & $6 \%$ & $25 \%$ & $69 \%$ & $0 \%$ & $0 \%$ \\
\hline ARTIGO & $10 \%$ & $0 \%$ & $50 \%$ & $20 \%$ & $20 \%$ \\
\hline
\end{tabular}

Fonte: Quadro elaborado a partir dos dados coletados pela pesquisadora (Maio/2016).

Os números apresentados nos levam a refletir sobre as açōes de letramento acadêmico na universidade. Como já citado, o letramento acadêmico é um novo letramento, ainda năo experienciado pelos alunos. Tudo é novo e é necessário familiarizar-se com os novos gêneros que agora têm acesso (MARINHO, 2010), alfabetizando-se no ensino superior (OLIVEIRA, 2011). E para que isso ocorra e necessário explanaçăo, orientaçăo e correçấo.

A pouca explicaçăo sobre os gêneros é algo que os universitários sentem falta, e o motivo pelo qual produzem pouco e de forma equivocada. Em algumas falas, os alunos admitem ter escrito pouco durante o curso, e quando văo produzir precisam recorrer à cópia. Em suas complementaçôes das repostas dadas, os alunos A5 e B1 admitem que escreveram os textos solicitados apenas por obrigaçấo. Essa experiência de produçâo está atrelada a um mero processo de mecanizaçăo de açóes, levando ao chamado letramento autônomo apontado por Lea e Street (1998; 2006).

Sobre essa necessidade de orientaçâo (preparo para a produçâo) Kersch também se posiciona muito pontualmente:

Cada um de nós é desafiado quando está diante do novo, diante de um gênero nunca produzido. É o que provavelmente acontece com nossos alunos, quando se veem diante dessa tarefa. Falta dar a quem produz textos, alunos e professores, as orientaçóes adequadas e completas, acesso a vários textos do gênero, para que analisem, comparem, percebam a estrutura, a linguagem social da esfera em que esse gênero circula. Muitas vezes, falta trabalho efetivo com o gênero antes de chegar à produçăo. (2014, p. 62)

Souza e Basseto (2014, p. 99) também discorrem sobre a orientaçăo na produçâo dos GTAs e complementam o que a falta desse processo ao afirmarem que

[...] assim, os alunos acabam por pressupor, a partir de suas notas - atribuídas em provas e trabalhos -, o que é ou náo um texto acadêmico, perdendo-se, com isso, a concepçáo de propósito comunicativo dos gêneros acadêmicos, visto que muitos desses textos acadêmicos săo produzidos apenas para avaliaçăo.(SOUZA; BASSETO, 2014, p. 99)

E essa pseudo concepçăo dos GTAs é muitas vezes estabelecida em virtude da năo orientaçâo e náo correçấo dos trabalhos realizados como podemos observar no item a seguir.

\section{- Açōes pós a produçáo dos GTAs}

Visando conhecer o que acontece pós a produçâo dos GTAs pelos alunos, questionamos se recebiam devolutiva dos trabalhos por parte dos professores e se havia 
justificativa da nota atribuída. Vejamos os números obtidos:

Quanto às produções desse gênero, você recebeu devolutiva (trabalho com correção e justificação da nota atribuída)?

\begin{tabular}{c|c|c|c|c|c}
\hline 8' PERÍODO & Sempre & Muitas vezes & Poucas vezes & Nenhuma vez & Não me lembro \\
\hline FICHAMENTOS & $0 \%$ & $0 \%$ & $61 \%$ & $22 \%$ & $17 \%$ \\
\hline RESUMO & $0 \%$ & $17 \%$ & $59 \%$ & $18 \%$ & $6 \%$ \\
\hline RESENHA & $0 \%$ & $12 \%$ & $53 \%$ & $23 \%$ & $12 \%$ \\
\hline ARTIGO & $0 \%$ & $0 \%$ & $31 \%$ & $50 \%$ & $19 \%$ \\
\hline
\end{tabular}

Fonte: Quadro elaborado a partir dos dados coletados pela pesquisadora (Maio/2016).

Quanto às produções desse gênero, você recebeu devolutiva (trabalho com correção e justificação da nota atribuída)?

\begin{tabular}{c|c|c|c|c|c}
\hline 9o PERÍODO & Sempre & Muitas vezes & Poucas vezes & Nenhuma vez & Não me lembro \\
\hline FICHAMENTOS & $17 \%$ & $6 \%$ & $65 \%$ & $12 \%$ & $0 \%$ \\
\hline RESUMO & $12 \%$ & $19 \%$ & $50 \%$ & $19 \%$ & $0 \%$ \\
\hline RESENHA & $6 \%$ & $25 \%$ & $63 \%$ & $6 \%$ & $0 \%$ \\
\hline ARTIGO & $17 \%$ & $8 \%$ & $41 \%$ & $17 \%$ & $17 \%$ \\
\hline
\end{tabular}

Fonte: Quadro elaborado a partir dos dados coletados pela pesquisadora (Maio/2016).

O resultado em ambas as turmas elucida uma realidade que merece atençăo: o retorno do que é produzido pelos alunos ainda é pouco e a justificativa e compreensâo da nota atribuída está distante da ideal. Diante disso, nos questionamos: a solicitaçăo desses GTAs nâo é parte do processo de ensino e aprendizagem universitário? O que aprendem ao produzir um desses gêneros em uma determinada disciplina nâo o auxiliará na produçâo seguinte em outra disciplina? O que se corrige em uma produçăo năo é usado como base em outra? Ainda: a produçấo por produçâo sem um aprendizado efetivo năo se configura como uma perca de tempo e mero cumprimento de protocolo? A resposta a tais perguntas, diante do alegado pelos alunos, é "năo" ou "muito pouco", o que nos preocupa.

Em sua fala, a estudante A15 reclama que "muitos professores (grande maioria) devolvem os trabalhos com uma nota, mas năo justificam o porquê, năo apresenta os erros e os acertos, entăo fica muito difícil você melhorar e ver o que deve ser concertado". Durante a análise das respostas dadas a essa pesquisa, observa-se, em muitas falas, que poucas vezes houve a devoluçăo desses trabalhos, e para nos preocupar ainda mais, os alunos destacam que sentem falta disso, relatam que nem imaginam como conseguiram atingir a média, citando em alguns casos que escreveram totalmente fora das normas e regras apropriadas.

Um dos fatores que podemos justificar a falta desse retorno alegado pelos alunos é que muitos professores só realizam a correçāo dos trabalhos acadêmicos no final de semestre e como em muitos casos o professor e aluno náo se encontram mais, a devolutiva e comentários sobre as produçôes ficam sem ser realizados. 
Essa falta de feedback dificulta o processo de ensino e aprendizado do aluno. Ao ver no que erraram, o que pode ser corrigido, e o que pode ser melhorado, o aluno poderia ter uma melhor compreensáo e mais motivaçâo para aprender e tentar melhorar a cada dia seu letramento acadêmico.

Isso porque, na medida em que o professor percebe o erro como uma ferramenta importante para a avaliaçăo e aprendizado, tanto dele como do aluno, consegue ajudar o estudante fazendo com que ele perceba, no erro, aquilo que o mesmo já aprendeu sobre o conteúdo estudado e aquilo que ainda náo ficou claro; assim buscará outras ferramentas de aprendizagem para compreender e melhorar na próxima execuçāo do conteúdo que o foi apresentado. É preciso refletir sobre a forma de avaliaçăo que está sendo empregada, se está servindo apenas para aprovar, sem levar em conta o conhecimento e a melhoria na aprendizagem. É o que aponta Cunha:

Cada indivíduo ou grupo social possui algum tipo de conhecimento sobre a escrita bem como de seu uso em práticas sociais. Assim sendo, os alunos que ingressam na Universidade, acima de tudo săo sujeitos e, além disto, săo sujeitos letrados que trazem consigo concepçóes de leitura e escrita construídas numa vida submetida a um contexto social. Porém, apesar de letrados, năo conseguem apresentar bom desempenho na universidade ou, quando conseguem tal performance, inesperada para muitos, esta é justificada pela máxima de que "o professor finge que ensina, o aluno finge que aprende, e todos sâo felizes". Em outros dizeres, trabalha-se com conteúdos rasos e avaliaçóes desonestas. (CUNHA, 2012, p.139)

Observa-se, porém que, segundo os alunos, a correçăo dos GTAs pouco é realizada por parte dos professores, o que acaba elucidando o porquê esses estudantes em nível avançado do curso ainda năo se consideram preparados para produzir fichamentos, pouco sabem diferenciar resenha de resumo, um artigo, ou projeto de iniciaçăo científica. Outro dado que explica a falta de familiaridade desses estudantes com determinados gêneros é que, como eles mesmos relatam, os trabalhos foram feitos apenas para a obtençăo de notas.

\section{- Relaçăo entre a quantidade pedida de produçăo dos GTAs e a necessária}

A partir da observaçâo dos dados foi constatado que muitos alunos demonstram um certo arrependimento por năo ter aproveitado o curso, produzindo, publicando, e aumentando o repertório de leituras.

Diante disso, podemos pressupor que a atuaçăo efetiva na comunidade acadêmica, quando se dá, é realizada a partir de "adaptaçóes" que ocorreriam "naturalmente", do ponto de vista desses alunos, em relaçáo à academia e năo a um processo de conscientizaçâo em relaçâo às práticas sociais e discursivas existentes nela. Entretanto faz-se necessária a conscientizaçăo desses alunos em relação aos gêneros acadêmicos - e seus propósitos comunicativos específicos - e ao discurso acadêmico. (SOUZA; BASSETO, 2014, p.101)

Sobre essa questăo da consciência da necessidade do aprendizado efetivo nas produçóes acadêmicas, muitos alunos se manifestaram e alguns desses discursos merecem ser refletidos. Um exemplo é o desabafo do aluno A11, que menciona que esse processo passou despercebido durante sua vida acadêmica:

Antes era apenas uma forma de adquirir notas nas disciplinas. Hoje vejo que poderia 
ter explorado mais em minhas leituras, pois nâo há forma de conhecimento maior e melhor que a leitura, e a partir daí poderia escrever com mais discernimento e desenvoltura. $O$ erro nâo só foi dos professores, mas primeiramente meu. (Aluno A11)

Essa posiçâo do aluno A11pode ser reforçada a partir da análise dos dados coletados, pois para a maioria dos alunos das turmas assume que esse processo de produçáo dos GTAs poderia ter sido mais explorado, como também apontado pelos alunos em muitas de suas respostas.

\section{ALGUMAS CONSIDERAÇÕES}

Na pesquisa realizada e apresentada aqui objetivamos discutir o letramento acadêmico no que tange a produçâo dos GTAs. A pesquisa realizada com alunos formandos ( $8^{\circ}$ e $9^{\circ}$ período) do curso de Pedagogia da Universidade Federal do Tocantins, Campus de Arraias (2016), revelou que os universitários em questăo encontram dificuldades em compreender o real sentido de letramento acadêmico, e também em produzir os gêneros textuais específicos da área acadêmica.

Por ter sido realizado a pesquisa com dois períodos de turnos diferentes, esperávamos levantar dados distintos devido ao perfil (a idade, disponibilidade para estudos e espaço entre o término do EM e a entrada na Universidade) o que năo se pode constar.

A partir das análises da fala dos estudantes, chegamos à conclusâo de que é importante rever os conceitos sobre a formaçáo acadêmica quando nos referimos a escrita, mais especificadamente de gêneros acadêmicos. Dentre as conclusôes apontadas, constata-se o alerta para o fato de que, mesmo sendo turmas em fase final do curso, a produçăo escrita dos GTAs ainda é muito pequena. No que concerne ao contato com os GTAs, os alunos leem uma maior variedade de gêneros do que produzem, ficando mais evidente a produçáo de resumos, fichamentos e resenhas, utilizados com muita frequência apenas para a obtençâo de notas e como forma de avaliaçăo por parte dos professores (integralizaçăo de notas) e há pouco retorno das produçóes realizadas.

Foi observado que os aspectos da escrita produzida na universidade chamam mais a atençâo dos estudantes quando passam a refletir sobre ela. Também se observou uma queixa frequente quanto à forma de avaliaçăo dessas produçóes, no que se refere à clareza de critérios avaliados e de explanaçâo sobre o que houve de acerto e o que precisa ser melhorado nessas produçôes. Segundo boa parte dos entrevistados, náo há um retorno das atividades principalmente contendo esses elementos.

Outro ponto a ser destacado é a referência a aspectos como "organizaçăo" e "clareza", que parece continuarem tâo vagos e genéricos como sempre sáo tratados no ensino da escrita. Isso ocorre pelo fato dos professores pensarem que os alunos já chegam dominando sobre o assunto. A falta de explanaçăo sobre tais gêneros causa estranhamento dos alunos quanto aos GTAs.

Marinho (2010) menciona que "professores e alunos săo vítimas de dificuldades que podem ser amenizadas se houver um investimento na compreensăo dos problemas em torno dessa temática e em açôes propositivas". Desta forma, como afirma a autora, "as melhores formas para amenizar essas lacunas é a participaçăo dos alunos 
em práticas de leitura, pois dependem das estratégias pedagógicas agenciadas pelos professores das diversas disciplinas e de projetos pedagógicos voltados para esse conteúdo" (MARINHO, 2010, p. 384). Portanto, com aponta Souza e Basseto:

[a]ntes da exigência da produçáo de gêneros acadêmicos por pesquisadores novatos nessa comunidade discursiva, é preciso que esses pesquisadores sejam preparados para essa inserçăo e atuaçáo na comunidade acadêmica. Em síntese, fazse urgente que a formaçăo de professores/ pesquisadores, em algumas situaçóes, seja repensada de modo a preparar tais pesquisadores para a produçáo de gêneros acadêmicos, tornando-se, assim, letrados. (SOUZA; BASSETO, 2014, p. 90)

Diante desses dados, concluímos que, apesar de estarmos falando de estudantes universitários, estes ainda nâo se encontram familiarizados com a ideia de gêneros acadêmicos. Dessa forma, podemos afirmar que năo há um processo completo de letramento desses alunos em relaçăo à escrita acadêmica, já que, pouco se lê e pouco se produz. Seria necessário repensar o papel da universidade com relaçăo à inserçấo real desses graduandos na comunidade acadêmica. 


\section{REFERÊNCIAS}

ARANHA, Solange. Contribuiçōes Linguísticas para a argumentaçăo da introduçâo acadêmica. 2004. 184 f. Tese (Doutorado em Letras/Linguística e Língua Portuguesa), Universidade Estadual Paulista "Júlio de Mesquita Filho", Campus de Araraquara, Araraquara, 2004.

CHAER, Galdino; DINIZ, Rafael Rosa Pereira; RIBEIRO, Elisa Antônia. A técnica do questionário na pesquisa educacional. In: Evidência. v. 7, n. 7, pp. 251-266, Araxá, 2011.

CUNHA, Jaeder Fernandes. Letramento Acadêmico: reflexāo e algumas consideraçôes sobre cursos de negócios em faculdades privadas populares. SIGNUM: Estud. Ling., Londrina, n. 15/2, pp. 129-151, dez. 2012.

DORSA, Arlinda Cantero. Os diferentes gêneros textuais utilizados na Universidade: o papel docente e discente neste caminhar. Cadernos do CNLF, Vol. XVII, No 03 - Minicursos e Oficinas. Rio de Janeiro: CiFEFiL, 2013. Disponível em: <http://www.filologia.org.br/ xvii_cnlf/min_ofic/08.pdf>. Acesso em: 14 de mar. de 2016.

FIAD, Raquel Salek. A escrita na universidade. Revista da ABRALIN, v. Eletrônico, n. Especial, pp. 357-369. $2^{\mathrm{a}}$ parte, 2011.

FISCHER, Adriana. Letramento acadêmico: uma perspectiva portuguesa. Acta Scientiarum. Language and Culture. Maringá. jul./dez., v. 30, n. 2, pp. 177-187, 2008.

GIL, Antônio Carlos. Métodos e técnicas de pesquisa social. 5. ed. Sáo Paulo: Atlas, 2006.

GONÇALVES, Sheila de Carvalho Pereira. A importância da análise de gêneros textuais na formaçăo docente. Cadernos da FUCAMP, v.11, n.15, p.129-146. 2012. Disponível em: 〈http://www.fucamp.edu.br/editora/index.php/cadernos/article/download/261/231 . Acesso em: 15 de mar. de 2016.

LEA, Mary R.; STREET, Brian V. Student writing in higher education: an academic literacies approach. Studies in Higher Education, v. 23, n. 2, pp. 157-172, jun. 1998.

The "academic literacies" model: theory and applications. Theory Into Practice, v. 45, n. 4, pp. 368-377, 2006. Disponível em: <http://www3.unisul.br/ paginas/ ensino/pos/linguagem/cd/English/22i.pdf>. Acesso em: 26 ago. 2016.

MARCUSCHI, Luis Antonio. Gêneros textuais: definiçăo e funcionalidade. In:

Gêneros textuais e ensino. Rio de Janeiro: Lucena, 2003, pp. 19-36

MARINHO, Marildes. A escrita nas práticas de letramento acadêmico. RBLA, Belo Horizonte, v. 10, 2010.

MINAYO, Maria Cecília de Souza. Análise qualitativa: teoria, passos e fidedignidade. Ciência e saúde coletiva, Rio de Janeiro, 2012.

NEVES, José Luis. Pesquisa Qualitativa: Características, usos e possibilidades. Caderno de pesquisas em Administraçăo. Săo Paulo, 1996. Disponível em: <http://www.unisc.br/ portal/upload/com_arquivo/pesquisa_qualitativa_caracteristicas_usos_e_possibilidades. pdf>. Acesso em: 15 de mar. de 2016. 
OLIVEIRA, Eliane Feitosa. Letramento Acadêmico: Principais abordagens sobre a escrita dos Alunos no ensino superior. UNICAMP, 17 Congresso de Leitura (COLE), 2011.

BRASIL. Secretaria de Educaçâo Fundamental. Parâmetros Curriculares Nacionais: terceiro e quarto ciclos do ensino fundamental: Língua Portuguesa. Brasília: MEC/SEF, 1998.

SOUZA, Micheli Gomes; BASSETO, Lívia Maria Turra. Os processos de apropriaçăo de gêneros acadêmicos (escritos) por graduandos em Letras e as possíveis implicaçôes para a formaçăo de professores/pesquisadores. RBLA, Belo Horizonte, v. 14, n. 1, pp. 83-110, 2014.

TFOUNI, Leda Verdiani. Letramento e Alfabetizaçăo. 8. ed. Săo Paulo: Cortez, 2006.

KERSCH, Doratea Frank. O letramento acadêmico na formaçăo continuada: constituiçăo de autoria e construçấo de identidades. Revista do Programa de Pós-Graduaçáo em Letras da Universidade de Passo Fundo, v. 10, n. 1, pp. 53-63 - jan. /jun. 2014. 


\section{RESENHA}

FIAD, Raquel Salek (Org.). Letramentos acadêmicos: contexto, práticas e percepções. São Carlos: Pedro \& João Editores, 2016. 357p.

Por: Wagner Rodrigues Silva (UFT/CNPq)

Os estudos do letramento têm se fortalecido, ao longo das últimas décadas, especialmente na Ciência da Educaçăo e na Linguística Aplicada. As pesquisas orientadas pelos referidos estudos surgiram em funçâo do trabalho pedagógico em torno das práticas escolares de alfabetizaçăo, as quais se mostravam pouco eficazes diante da democratizaçâo das instituiçôes brasileiras de ensino básico, acolhedoras de professores e alunos representantes de uma maior diversidade cultural e linguística (cf. SOARES, 2002).

Outras demandas de pesquisa surgiram motivadas por influências da tecnologia da escrita em diferentes atividades desempenhadas pelo homem, resultando em desdobramentos das teorias focalizadas, a exemplo dos estudos do letramento digital, letramento do professor e letramento acadêmico (cf. BRAGA, 2007; KLEIMAN; SIGNORINI, 2000; MARINHO; CARVALHO, 2010; SILVA, 2012). Apesar das especificidades dos estudos da escrita, essas ramificaçóes teóricas se complementam, conforme o leitor pode constatar na coletânea "Letramentos acadêmicos: contexto, práticas e percepçôes", editada por Pedro \& Joăo Editores e organizada por Raquel Salek Fiad, pesquisadora do Conselho Nacional de Desenvolvimento Científico e Tecnológico (CNPq) e professora titular do Departamento de Linguística Aplicada, na Universidade Estadual de Campinas (UNICAMP).

A coletânea é composta por dez capítulos com resultados de pesquisas a respeito dos impactos provocados por práticas sociais, atreladas à produçâo e à circulaçấo da escrita, no contexto universitário. Os letramentos acadêmicos, portanto, é a temática central dos trabalhos reunidos, mas sâo evidentes diálogos estabelecidos com outras especificidades dos estudos do letramento, haja vista os distintos contextos investigativos considerados nas pesquisas.

Mesmo năo distribuídos em seçôes explicitamente identificadas no sumário da coletânea, os capítulos foram organizados em quatro grandes momentos, que ilustram diálogos com outras especificidades dos estudos do letramento: (1) o primeiro e segundo capítulos focalizam forças institucionais incidentes em políticas para publicaçâo científica no contexto universitário; (2) o terceiro e quarto capítulos mostram algumas contribuiçōes na formaçăo de professores de práticas de escrita promovidas no contexto de um programa governamental de iniciaçăo à docência em licenciaturas brasileiras; (3) o quinto, sexto e sétimo capítulos ilustram a apropriaçâo de letramentos acadêmicos por universitários em situaçôes de produçăo escrita de diferentes gêneros discursivos; finalmente, (4) o oitavo, nono e décimo capítulos mostram o envolvimento de interaçōes mediadas por tecnologias digitais na constituiçăo da escrita produzida em contextos de instruçâo formal, universidade e escola básica.

A própria organizadora sinaliza esses quatro momentos na apresentaçâo da coletânea, quando comenta as pesquisas reunidas, as quais foram desenvolvidas e estudadas 
no grupo de pesquisa por ela coordenado. Além de ilustrar investigaçóes de diferentes práticas de letramentos acadêmicos, os capítulos evidenciam a relevância das variaçōes teórico-metodológicas construídas em torno de um percurso comum.

O leitor deve estar se perguntando quais sâo os principais diferenciais ou contribuiçōes da coletânea. Trata-se do primeiro livro a tematizar especificamente os estudos de letramentos acadêmicos, no âmbito da Linguística Aplicada produzida no Brasil. 0 mérito dos trabalhos produzidos năo se restringe à primogenitura da coletânea, mas inclui os percursos teóricos-metodológico construídos nas pesquisas. Ao investigar diferentes fenômenos do letramento, as escritas acadêmicas năo săo as únicas e, talvez, nâo sejam as principais unidades de análise. A relevância desse documento é compartilhada com outras fontes de pesquisa, que, de alguma forma, vinculam-se ao manuscrito acadêmico, resultando num movimento de visualizaçăo do que é aqui denominado de redes, tomando como referência Latour (1994, p. 12), ao caracterizá-las como "reais, e coletivas, e discursivas". Para tanto, destacam-se as palavras de Flávia Danielle S. S. Miranda, no oitavo capítulo, as quais ecoam as vozes das demais pesquisas compartilhadas: "investigaçōes atravessam as produçóes escritas de estudantes universitários, expandindo-se para outras práticas de letramentos acadêmicos, ampliando os interesses dos trabalhos sob esse enfoque" (p. 254).

O percurso investigativo proposto é resultado de diálogos estabelecidos entre diferentes referenciais teóricos, conforme demanda da complexidade do objeto investigado e alcance da açâo promovida pelas pesquisadoras. Os principais referenciais assumidos na coletânea sáo os Novos Estudos do Letramento e os estudos discursivos bakhtinianos. Uma tese assumida nos capítulos e que demanda maior esclarecimento é a defesa da Etnografia como teorizaçấo e nâo como uma metodologia. Nos termos de Raquel Salek Fiad, no sexto capítulo, a etnografia "coaduna com uma perspectiva dialógica, na medida em que considera textos em seu processo de construçáo no diálogo com outros textos nas histórias de letramentos" (p. 210).

Finalmente, destaca-se que os interesses dos leitores sâo diversos, portanto para cada encontro com a obra, diferentes respostas podem ser geradas para o questionamento previamente levantado sobre o diferencial da coletânea. Nesta resenha, foram selecionadas duas das contribuiçôes visualizadas, outras ficam por conta dos leitores curiosos, especialmente estudiosos da linguagem e, até mesmo, especialistas vinculados a outras áreas do conhecimento, todos envolvidos em interaçóes acadêmicas mediadas pela escrita. Os leitores estáo convidados a conhecerem mais de perto os trabalhos científicos produzidos pela competente equipe de linguistas aplicados, representada pela Prof. Dra. Requel Salek Fiad (UNICAMP/CNPq). 


\section{REFERÊNCIAS}

BRAGA, Denise B. Letramento na internet: o que mudou e como tais mudanças podem afetar a linguagem, o ensino e o acesso social. In: Angela B. Kleiman; Marilda C. Cavalcanti (Orgs.). Linguística Aplicada: suas faces e interfaces. Campinas: Mercado de Letras, 2007, pp. 181-198.

KLEIMAN, Angela B.; SIGNORINI, Inês (Orgs.). 0 ensino e a formaçăo do professor: alfabetizaçăo de jovens e adultos. Porto Alegre: Artmed, 2000.

LATOUR, Bruno. Jamais formos modernos. Traduçâo de Carlos Irineu da Costa. Rio de Janeiro: Editora 34, 1994.

MARINHO, Marildes; CARVALHO Gilcinei T. (Orgs.). Cultura escrita e letramento. Belo Horizonte: Editora da UFMG, 2010.

SILVA, Wagner R. (Org.). Letramento do professor em formaçăo inicial: interdisciplinaridade no estágio supervisionado da licenciatura. Campinas: Pontes Editores, 2012.

SOARES, Magda. Linguagem e escola: uma perspectiva social. 17. ed. Sáo Paulo: Ática, 2002. 